Article

\title{
Synthesis, Characterization and Wettability of Cu-Sn Alloy on the Si-Implanted $6 \mathrm{H}-\mathrm{SiC}$
}

\author{
Xiang Zhao Zhang ${ }^{1}$, Pu Hao Xu ${ }^{1}$, Gui Wu Liu ${ }^{1,2, *}$, Awais Ahmad ${ }^{3}{ }^{(0)}$, Xiao Hui Chen ${ }^{1,2}$, \\ Ya Long Zhu ${ }^{1}$, Asma Alothman ${ }^{4, * \mathbb{D}}$, Shahid Hussain ${ }^{1, * \mathbb{D}}$ and Guan Jun Qiao ${ }^{1}$ \\ 1 School of Materials Science and Engineering, Jiangsu University, Zhenjiang 212013, China; \\ xzzhang2018@ujs.edu.cn (X.Z.Z.); 13667004282@163.com (P.H.X.); chenxiaohui058@163.com (X.H.C.); \\ 18852897590@163.com (Y.L.Z.); gjqiao@ujs.edu.cn (G.J.Q.) \\ 2 School of Mechanical and Electrical Engineering, Xinyu University, Xinyu 338000, China \\ 3 Department of Chemistry, The University of Lahore, Lahore 54590, Pakistan; awaisahmed@gcuf.edu.pk \\ 4 Department of Chemistry, College of Science, King Saud University, Riyadh 11451, Saudi Arabia \\ * Correspondence: gwliu76@ujs.edu.cn (G.W.L.); aaalothman@ksu.edu.sa (A.A.); shahid@ujs.edu.cn (S.H.)
}

Received: 22 August 2020; Accepted: 14 September 2020; Published: 21 September 2020

check for updates

\begin{abstract}
The wettability of the metal/SiC system is not always excellent, resulting in the limitation of the widespread use of $\mathrm{SiC}$ ceramic. In this paper, three implantation doses of $\mathrm{Si}$ ions $\left(5 \times 10^{15}\right.$, $1 \times 10^{16}, 5 \times 10^{16}$ ions $\left./ \mathrm{cm}^{2}\right)$ were implanted into the $6 \mathrm{H}-\mathrm{SiC}$ substrate. The wetting of $\mathrm{Cu}-(2.5,5$, $7.5,10)$ Sn alloys on the pristine and Si-SiC were studied by the sessile drop technique, and the interfacial chemical reaction of $\mathrm{Cu}-\mathrm{Sn} / \mathrm{SiC}$ wetting couples was investigated and discussed. The $\mathrm{Si}$ ion can markedly enhance the wetting of $\mathrm{Cu}-\mathrm{Sn}$ on $6 \mathrm{H}-\mathrm{SiC}$ substrate, and those of the corresponding contact angles $(\theta)$ are raised partly, with the $\mathrm{Si}$ ion dose increasing due to the weakening interfacial chemical reactions among four $\mathrm{Cu}-\mathrm{Sn}$ alloys and $6 \mathrm{H}-\mathrm{SiC}$ ceramics. Moreover, the $\theta$ of $\mathrm{Cu}-\mathrm{Sn}$ on (Si-)SiC substrate is first decreased and then increased from $\sim 62^{\circ}$ to $\sim 39^{\circ}$, and $\sim 70^{\circ}$ and $\sim 140^{\circ}$, with the Sn concentration increasing from $2.5 \%, 5 \%$ and $7.5 \%$ to $10 \%$, which is linked to the reactivity of $\mathrm{Cu}-\mathrm{Sn}$ alloys and $\mathrm{SiC}$ ceramic and the variation of liquid-vapor surface energy. Particularly, only a continuous graphite layer is formed at the interface of the $\mathrm{Cu}-10 \mathrm{Sn} / \mathrm{Si}-\mathrm{SiC}$ system, resulting in a higher contact angle $\left(>40^{\circ}\right)$.
\end{abstract}

Keywords: $6 \mathrm{H}-\mathrm{SiC}$; $\mathrm{Cu}-\mathrm{Sn}$ alloy; ion implantation; wettability; interface

\section{Introduction}

Silicon carbide $(\mathrm{SiC})$ has been widely applied in the field of electronics industries and metal-ceramic composites, due to its sublime properties such as high strength, high modulus, high melting point and erosion resistance [1-3]. In fact, good wettability between liquid metals and $\mathrm{SiC}$ ceramic plays a vital role in these areas. Up to now, two critical challenges for the SiC applications are the low wettability and the undesired interfacial reaction of metals and $\mathrm{SiC}$ ceramic [4]. Commonly, the equilibrium value of $\theta$, used to explore the wetting behavior of liquid on a flat and chemically homogeneous solid surface, observes the traditional Young's equation [5] $\cos \theta=\sigma_{S V}-\sigma_{S L} / \sigma_{L V}$ (where $\sigma_{S V}$ and $\sigma_{L V}$ describe the surface tension of the solid and liquid, respectively, and the $\sigma_{S L}$ defines the solid/liquid interfacial energy). Based on this equation, two leading technologies can be performed to reduce the $\theta$ of metal on the $\mathrm{SiC}$ substrate.

One is increasing the $\sigma_{S V}$ by changing the $\mathrm{SiC}$ surface (i.e., the ion implantation, Ref. [6] sintering metallization $[7,8]$ and plasma pulses [9]. Compared with other surface modification technologies, ion implantation is a non-thermal and non-equilibrium process, where no new interface is introduced and the surface crystal structure can be altered in this process [10]. Recently, our group has proved 
that Mo, Ref. [11] Pd [12] and Si [13] ion implantation can increase the $\sigma_{S V}$ of $6 \mathrm{H}-\mathrm{SiC}$ monocrystal substrate by producing lattice imperfections and point defects, and thus the ion implantation is regarded as one of the key factors affecting the wettability of Al, Ref. [13] Al-Cu and [13] Al-Si-(Cu, Mg or Zn) [6,12] on $\mathrm{SiC}$ monocrystal substrate. For instance, $\mathrm{Zhu}$ et al. [13] studied the wetting of $\mathrm{Al}-\mathrm{Cu} / \mathrm{Si}$-implanted $\mathrm{SiC}$ wetting couples, indicating that the contact angles of $\mathrm{Al}-\mathrm{Cu}$ alloys on $\mathrm{Si}-\mathrm{SiC}$ substrates were raised partly with an increase of the $\mathrm{Si}$ ion dose, and the $\mathrm{Si}$ ion can evidently improve the wetting of $\mathrm{Cu}-\mathrm{Al} / \mathrm{SiC}$ when the content of $\mathrm{Al}$ is no more than $42.9 \%$ in $\mathrm{Cu}$.

Another is adding elements such as (Ti, Ref. [14,15] Cr, Ref. [16] Ni [17]) into the metal to reduce the $\sigma_{S L}$ by enhancing the interfacial interactions of metal/SiC systems and/or to simultaneously reduce the $\sigma_{L V}$. For the pure $\mathrm{Cu} / \mathrm{SiC}$ system, a high contact angle was detected due to the formation of the graphite layer at the wetting interface [18]. Various elements such as $\mathrm{Al}$ [13], Si [18], and $\mathrm{Zr}$ [19] were added into $\mathrm{Cu}$ to adjust the wettability of the $\mathrm{Cu} / \mathrm{SiC}$ system. As reported by Zhou et al. [19], excellent wettability $\left(\theta \approx 5^{\circ}\right)$ was observed in the $\mathrm{Cu}-\mathrm{Zr} / \mathrm{SiC}$ system at $1200{ }^{\circ} \mathrm{C}$, and the interfacial reaction layer was transformed from a graphite layer to metallic $\mathrm{ZrC}$ and $\mathrm{Zr}_{2} \mathrm{Si}$ compounds after adding $\mathrm{Zr}$ into $\mathrm{Cu}$. Furthermore, the other elements added into the pure metal can also bring about the changes of heat transfer performance compared with the pure metal [20-22], which can significantly affect the thermodynamic and kinetics of the chemical reaction between molten metal and ceramic during the wetting process. Therefore, the wettability of metal/ceramic system is further influenced accordingly.

As discussed above, both the surface modification of $\mathrm{SiC}$ and other metal element additions are the most promising methods to improve the wetting of metal/SiC systems. However, the influence of $\mathrm{Sn}$ addition on the wettability of the $\mathrm{Cu} / 6 \mathrm{H}-\mathrm{SiC}$ system was rarely reported, especially for the $6 \mathrm{H}-\mathrm{SiC}$ ceramic after $\mathrm{Si}$ ion implantation. Herein, $\mathrm{Si}$ ion was implanted into the $6 \mathrm{H}-\mathrm{SiC}$ monocrystal substrate, and the wettability of $\mathrm{Cu}-(2.5,5,7.5,10) \mathrm{Sn}$ (all in at.\% in this text) alloys on $6 \mathrm{H}-\mathrm{SiC}$ monocrystal substrate were investigated. We found that the $\mathrm{Si}$ ion can markedly enhance the wetting of $\mathrm{Cu}-\mathrm{Sn}$ on $6 \mathrm{H}-\mathrm{SiC}$ substrate, and the $\theta$ of $\mathrm{Cu}-\mathrm{Sn}$ on (Si-)SiC substrate basically decreases first, and then increases alongside the $\mathrm{Sn}$ concentration.

\section{Experimental Details}

The double polished C-terminated 6H-SiC monocrystal (CAS: 409-21-2), with sizes of $10 \mathrm{~mm} \times 10 \mathrm{~mm} \times 0.33 \mathrm{~mm}$, was employed as the wetting substrate. The $\mathrm{Cu}-(2.5,5,7.5,10) \mathrm{Sn}$ alloys used for the wetting experiments were fabricated by arc melting with non-consumable tungsten electrode under a purified $\operatorname{Ar}$ (99.99\%, CAS: 7440-37-1) atmosphere, and being remelted five times to ensure a uniform composition, combining appropriate amounts of the Cu sheet (99.9 wt.\% purity, CAS: 7440-50-8) and Sn granular (99.8 wt.\% purity, CAS: 7440-31-5). In order to prevent the oxygen contamination, a Ti getter (CAS: 7440-32-6) was melted first, before the $\mathrm{Cu}-\mathrm{Sn}$ alloy. The microstructure and phase composition of a typical $\mathrm{Cu}-7.5 \mathrm{Sn}$ alloy were analyzed and identified by scanning electron microscopy (SEM, FEI NovaNano450, back-scattered electron (BSE) mode) and X-ray diffraction (XRD). The scanning range of XRD examination was $20^{\circ}-90^{\circ}$, with a speed of $5^{\circ} / \mathrm{min}$. The $\mathrm{Cu}-\mathrm{Sn}$ alloys featured a wire electrode cutting into the block, with sizes of $3 \mathrm{~mm} \times 3 \mathrm{~mm} \times 3 \mathrm{~mm}$, which were carefully cleaned in acetone and ethanol successively before wetting experiments. The ion implantation was carried out in an ion implanter (MEVVA-36), and three doses of Si ions $\left(5 \times 10^{15}, 1 \times 10^{16}, 5 \times 10^{16} \mathrm{ions} / \mathrm{cm}^{2}\right)$ were implanted into the $6 \mathrm{H}-\mathrm{SiC}$ substrate at $20 \mathrm{keV}$ at an ambient temperature under the vacuum of $\sim 5 \times 10^{-3} \mathrm{~Pa}$.

The sessile drop tests of $\mathrm{Cu}-\mathrm{Sn}$ alloys on a Si-implanted $\mathrm{SiC}$ substrate were performed at a contact angle computing instrument (OCA15LHT-SV, Dataphysics, Filderstadt, Germany). The wetting samples were performed at $1373 \mathrm{~K}$ for $240 \mathrm{~min}$ in a vacuum of $\sim 6 \times 10^{-4} \mathrm{~Pa}$, with a heating rate of $5 \mathrm{~K} / \mathrm{min}$. After wetting experiments, the cross-sectioned wetting systems were polished using diamond polishing fluid, and the interfacial microstructure was observed by SEM (BSE mode), coupled with energy dispersive spectroscopy (EDS). It was noted that the images obtained from BSE mode can be used to evidently present the composition contrast for the polished samples, while the images 
obtained from the secondary electron (SE) model mainly reflect the contrasting information of the surface geometry.

\section{Results and Discussion}

Figure 1 shows the typical microstructure of Cu-7.5Sn alloy combined with its XRD pattern. The Cu-7.5Sn alloy presents a typical dendritic microstructure, and is composed of two phases (dark and grey phase). Based on the EDS analysis, both phases are mainly $\mathrm{Cu}$-rich solid solutions, where the $\mathrm{Sn}$ concentration in the grey phase is higher than that in the dark phase. According to the Cu-Sn binary phase diagram [23], the dark and grey phases can be confirmed as a Cu-rich solid solution $(\mathrm{Cu})$ and $(\mathrm{Cu})$ plus $\mathrm{Cu}-\mathrm{Sn}$ compounds. However, only the $(\mathrm{Cu})$ phase emerges in the XRD pattern due to the low content of the Cu-Sn compound (Figure 1b).

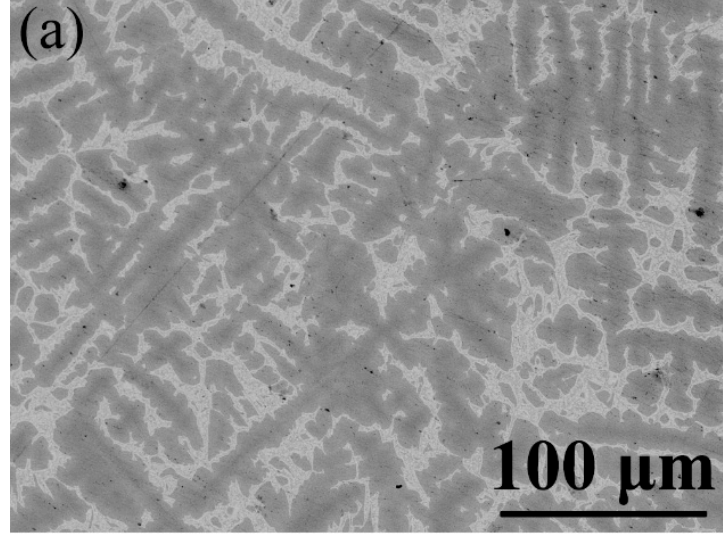

Figure 1. (a) Back-scattered electron (BSE) image; and (b) X-ray diffraction (XRD) pattern of Cu-7.5Sn alloy.

Figure 2 shows the wetting curves of molten $\mathrm{Cu}-(2.5,5,7.5,10) \mathrm{Sn}$ alloys on the ( $\mathrm{Si}-) \mathrm{SiC}$ substrates at $1373 \mathrm{~K}$. In Figure 2, two Y-axes are drawn to present the information of the contact angle (the $Y$-axis on the left). The temperature (the $Y$-axis on the right) in Figure 2a-d and the line corresponding to the wetting temperature is $1373 \mathrm{~K}$, showing a straight line in the figure. For the $\mathrm{Cu}-\mathrm{Sn} /$ pristine $\mathrm{SiC}$ systems, the contact angle $(\theta)$ is first decreased, and then increased from $\sim 62^{\circ}$ to $\sim 39^{\circ}$ and $\sim 70^{\circ}$, with the $\mathrm{Sn}$ concentration rising from $2.5 \%$ to $5 \%$ and $7.5 \%$. In particular, a non-wetting phenomenon with a high contact angle of $\sim 140^{\circ}$ is observed in the $\mathrm{Cu}-10 \mathrm{Sn} / \mathrm{SiC}$ system. On the other hand, the $\mathrm{Si}$ ion implantation has a pleasurable influence on the wetting of $\mathrm{Cu}-\mathrm{Sn} / \mathrm{SiC}$ couples. The $\theta$ of $\mathrm{Cu}-\mathrm{Sn}$ on the $\mathrm{Si}-\mathrm{SiC}$ substrate decreases markedly after $\mathrm{Si}$ ion implantation, especially for the $\mathrm{Cu}-10 \mathrm{Sn} / \mathrm{Si}-\mathrm{SiC}$ systems transforming from non-wetting to wetting. However, the $\theta$ of $\mathrm{Cu}-\mathrm{Sn} / \mathrm{Si}-\mathrm{SiC}$ systems is increased partly with the Si ion dose increase, rising up to $5 \times 10^{16}$ ions $/ \mathrm{cm}^{2}$. Those experimental results illustrate that the $\mathrm{Si}$ ion can blatantly improve the wettability of $\mathrm{Cu}-\mathrm{Sn} / \mathrm{SiC}$ systems. In contrast, a higher $\mathrm{Si}$ ion dose can weaken this phenomenon, showing an increased contact angle. In these cases, the $\sigma_{S V}$ keeps invariant (before ion implantation), or is increased due to the presence of the lattice imperfection and point defects after ion implantation [13], while the $\sigma_{L V}$ is decreased with the Sn concentration increasing, according to Amore's results [24]. Theoretically speaking, the increased $\sigma_{S V}$ or/and decreased $\sigma_{L V}$ can reduce the wettability of $\mathrm{Cu}-\mathrm{Sn} /(\mathrm{Si}-) \mathrm{SiC}$ systems based on Young's equation. Thus, the abnormally increased contact angle with the rise of the Si ion dose can be ascribed to the increased $\sigma_{L V}$ derived from the decreasing interfacial interactions between $\mathrm{Cu}-\mathrm{Sn}$ alloys and $\mathrm{Si}-\mathrm{SiC}$ ceramic. 

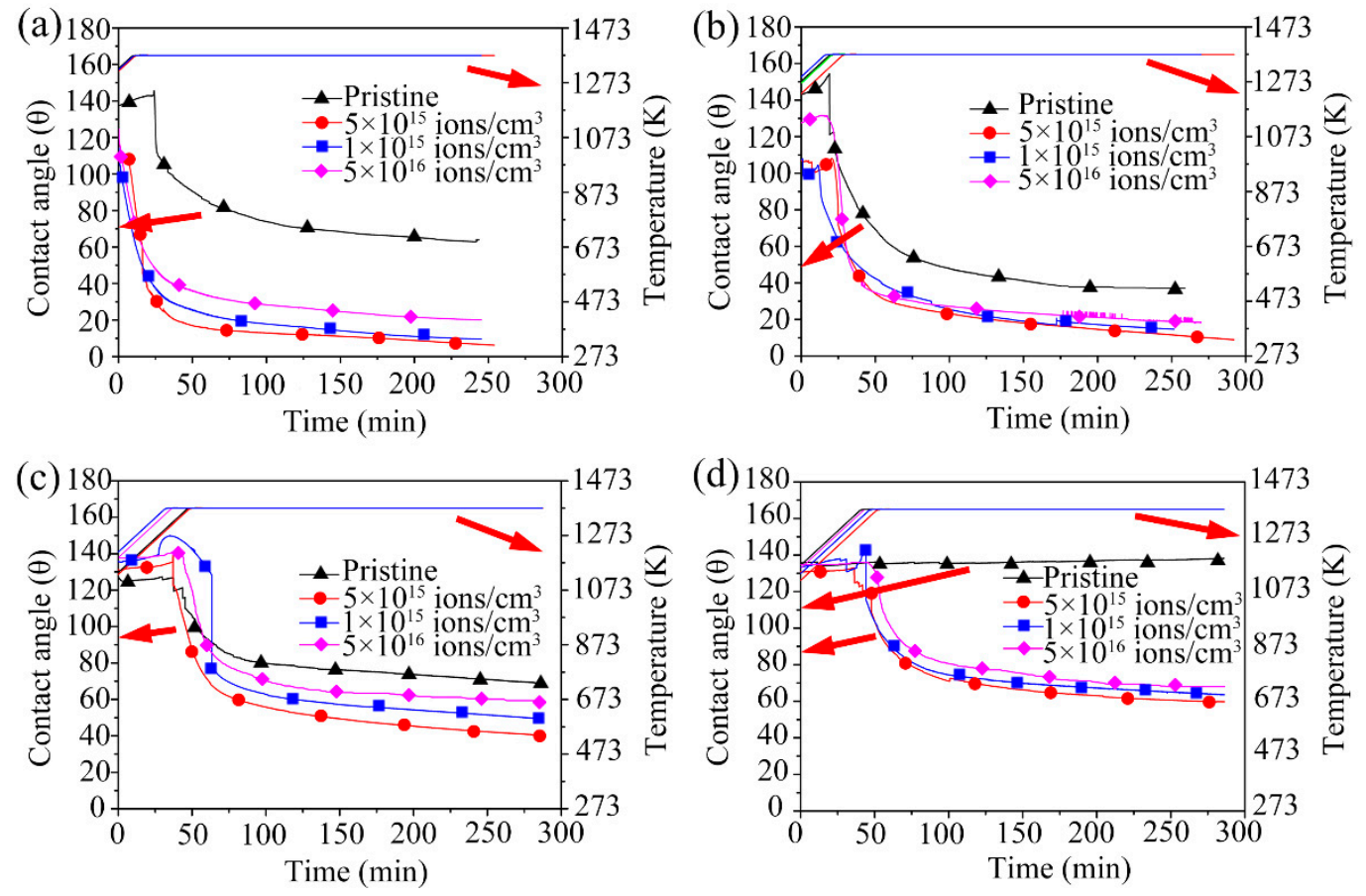

Figure 2. Curves of $\mathrm{Cu}-\mathrm{Sn} / \mathrm{SiC}$ systems before and after $\mathrm{Si}$ ion implantation $\left(5 \times 10^{15}, 1 \times 10^{16}\right.$ and $5 \times 10^{16}$ ions $/ \mathrm{cm}^{2}$ ) at $1373 \mathrm{~K}:(\mathbf{a}) \mathrm{Cu}-2.5 \mathrm{Sn}$; (b) Cu-5Sn; (c) Cu-7.5Sn; and (d) Cu-10Sn.

Figure 3 shows the interfacial BSE images of $\mathrm{Cu}-2.5 \mathrm{Sn} / \mathrm{SiC}$ couples before and after $\mathrm{Si}$ ion implantation. From Figure 3a, a prominent graphite layer and numerous $\mathrm{Cu}_{\mathrm{x}} \mathrm{Si}_{\mathrm{y}}$ compounds are formed at the surface of $\mathrm{Cu}-2.5 \mathrm{Sn}$ solidified drop due to the serious chemical reaction between $\mathrm{Cu}$ and $\mathrm{SiC}$, which is also observed in the pure $\mathrm{Cu}$ and $\mathrm{SiC}$ systems [13]. After $\mathrm{Si}$ ion implantation, a visible graphite film can be observed at the triple line region, and its width decreases with the $\mathrm{Si}$ ion dose increasing (Figure $3 \mathrm{~b}-\mathrm{d}$ ). Moreover, a laminated graphite layer is located on the upper part of the $\mathrm{Cu}-2.5 \mathrm{Sn}$ drop after $\mathrm{Si}$ ion implantation, as shown in Figure $3 \mathrm{f}-\mathrm{h}$. The laminated graphite layer gradually becomes thin, with the Si ion implantation dose rising, indicating that the interfacial interactions are weakened, resulting in an increase of $\sigma_{S L}$ and a contact angle, either more or less (as shown in Figures 2 and $3 \mathrm{i}-1$ ). Meanwhile, the $6 \mathrm{H}-\mathrm{SiC}$ substrate is more or less consumed with the formation of uneven scallops (Figure 3e-h). Similarly, the solidified $\mathrm{Cu}-2.5 \mathrm{Sn}$ drop consists of a dark phase marked A and a small amount of grey phase marked B, as shown in the insert image in Figure 3f. Based on the EDS results, the chemical compositions of the two phases are $92.09 \mathrm{Cu}+5.90 \mathrm{Si}+2.01 \mathrm{Sn}$ and $66.48 \mathrm{Cu}+33.52 \mathrm{Sn}$, respectively. According to the $\mathrm{Cu}-\mathrm{Si}$ and $\mathrm{Cu}-\mathrm{Sn}$ binary phase diagrams [23,25], the dark and grey phases can be confirmed as Cu-rich solid solutions, containing few $\mathrm{Cu}-\mathrm{Si}$ and $\mathrm{Cu}-\mathrm{Sn}$ compounds, respectively. 


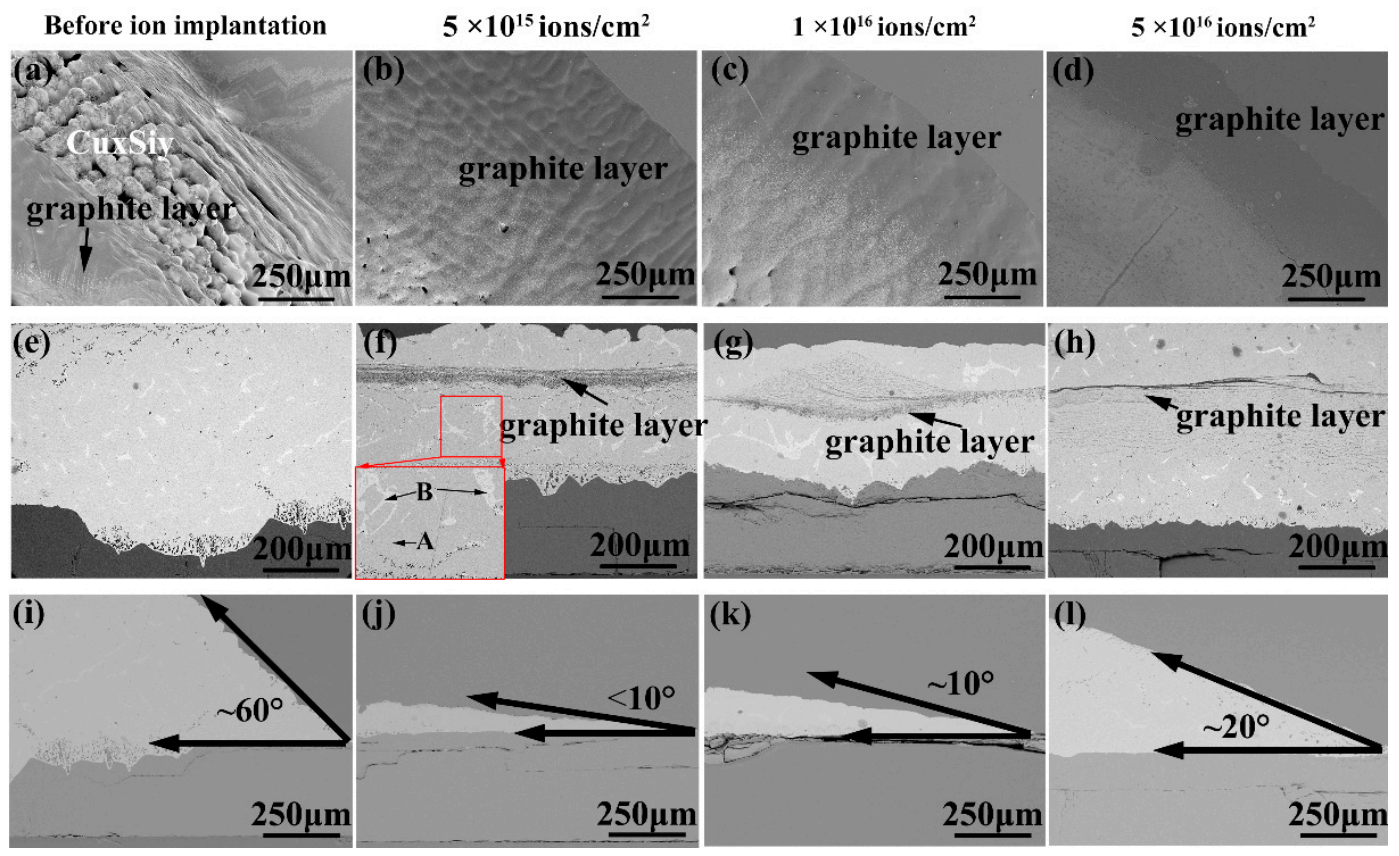

Figure 3. BSE images of $\mathrm{Cu}-2.5 \mathrm{Sn} /(\mathrm{Si}-) \mathrm{SiC}$ systems $(\mathbf{a}, \mathbf{e}, \mathbf{i})$ before and $(\mathbf{b}-\mathbf{d}, \mathbf{f}-\mathbf{h}, \mathbf{j}-\mathbf{l})$ after $\mathrm{Si}$ ion implantation: (a-d) at the triple line region, cross-section $(\mathbf{e}-\mathbf{h})$ at the central interfaces and $(\mathbf{j}-\mathbf{l})$ at the triple line region.

Figures 4 and 5 exhibit the top-view and interfacial BSE images of $\mathrm{Cu}-(5,7.5) \mathrm{Sn} / \mathrm{Si}$-SiC systems with different $\mathrm{Si}$ ion implantation doses, respectively. From Figure $4 \mathrm{a}, \mathrm{c}$, a thin graphite film emerges at the triple line region of $\mathrm{Cu}-(5,7.5) \mathrm{Sn} / \mathrm{Si}-\mathrm{SiC}$ systems after the $\mathrm{Si}$ ion implantation dose of $5 \times 10^{15} \mathrm{ions} / \mathrm{cm}^{2}$. However, a higher Si ion implantation dose $\left(5 \times 10^{16}\right.$ ions $\left./ \mathrm{cm}^{2}\right)$ cannot induce the formation of the graphite layer in Cu-(5, 7.5)Sn/Si-SiC systems (Figure $4 \mathrm{~b}, \mathrm{~d})$.

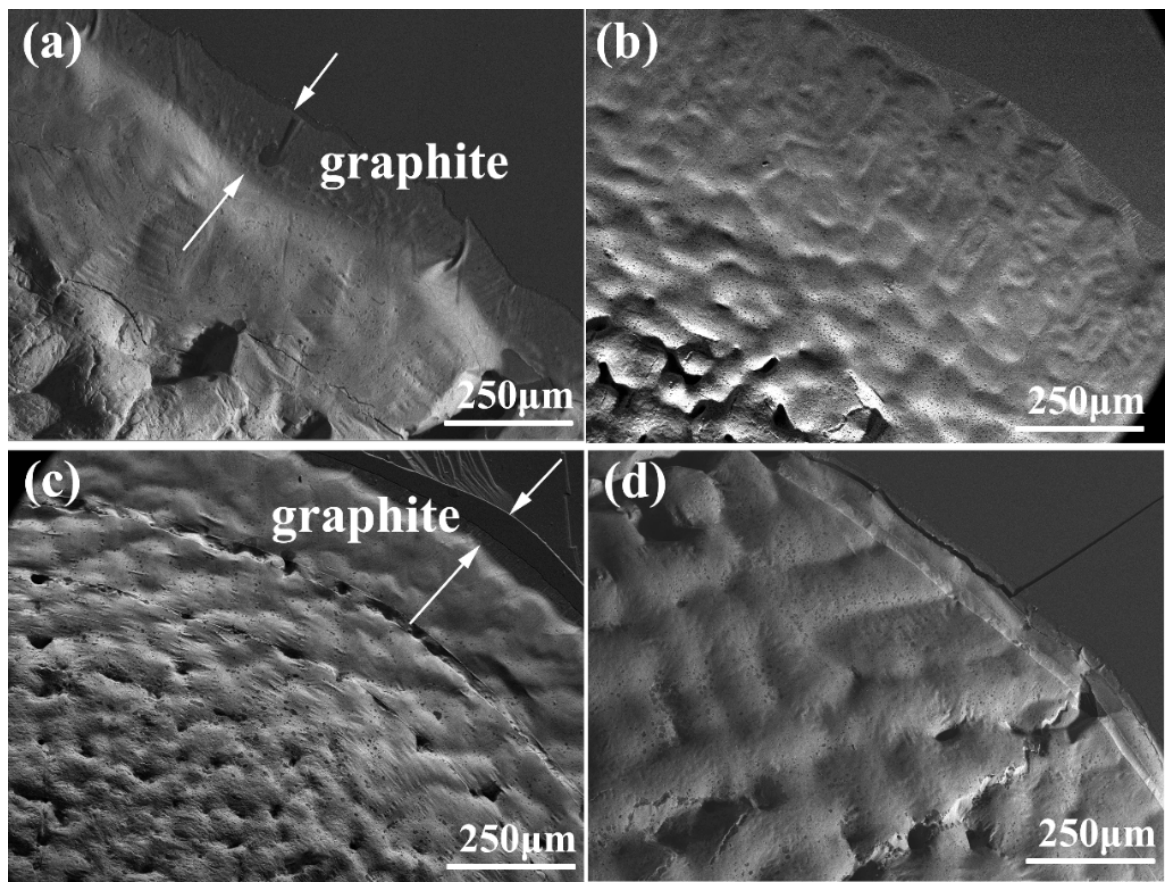

Figure 4. BSE images of $(\mathbf{a}, \mathbf{b}) \mathrm{Cu}-5 \mathrm{Sn} / \mathrm{Si}-\mathrm{SiC}$ and $(\mathbf{c}, \mathbf{d}) \mathrm{Cu}-7.5 \mathrm{Sn} / \mathrm{Si}-\mathrm{SiC}$ systems at the triple line region after Si ion implantation of $(\mathbf{a}, \mathbf{c}) 5 \times 10^{15}$ and $(\mathbf{b}, \mathbf{d}) 5 \times 10^{16}$ ions $/ \mathrm{cm}^{2}$. 

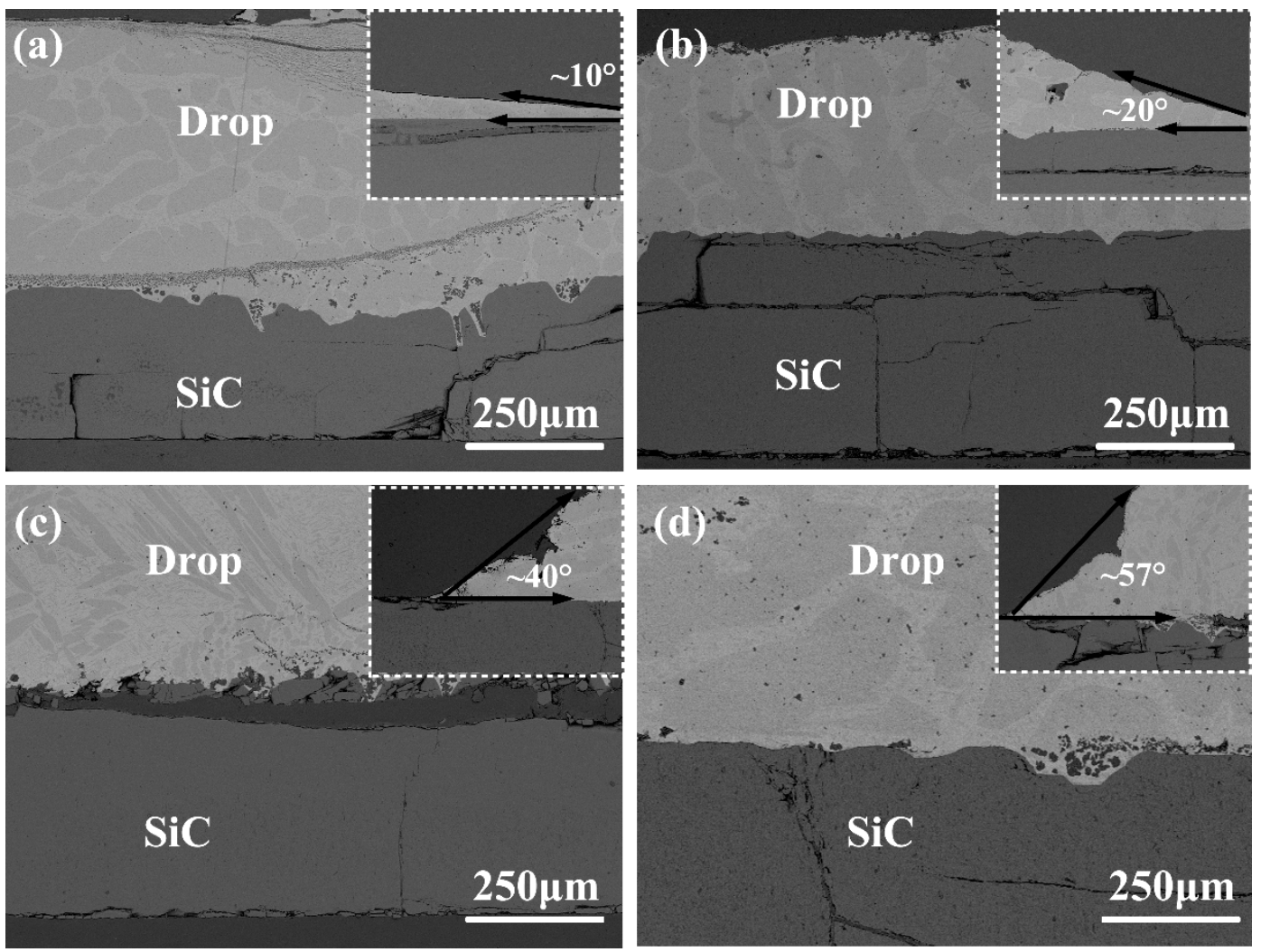

Figure 5. Interfacial BSE images of (a,b) $\mathrm{Cu}-5 \mathrm{Sn} / \mathrm{Si}-\mathrm{SiC}$ and $(\mathbf{c}, \mathbf{d}) \mathrm{Cu}-7.5 \mathrm{Sn} / \mathrm{Si}-\mathrm{SiC}$ systems at the central interfaces after Si ion implantation of $(\mathbf{a}, \mathbf{c}) 5 \times 10^{15}$ and $(\mathbf{b}, \mathbf{d}) 5 \times 10^{16} \mathrm{ions} / \mathrm{cm}^{2}$.

Compared to the $\mathrm{Cu}-2.5 \mathrm{Sn} / \mathrm{Si}-\mathrm{SiC}$ system, the $\mathrm{Cu}-(5,7.5) \mathrm{Sn} / \mathrm{Si}-\mathrm{SiC}$ presents relatively weak interfacial reactions, and the formed graphite layer moves closer to the $\mathrm{SiC}$ substrate (Figure 5). This phenomenon is mainly attributed to the low activity of $\mathrm{Cu}$, due to the relatively high concentration of the Sn element. As we know, the wettability of $\mathrm{Cu}-\mathrm{Sn} / \mathrm{Si}-\mathrm{SiC}$ couple can be comprehensively determined by the $\sigma_{S L}$ originating from interfacial interactions, and the $\sigma_{L V}$ on the condition of the same substrate. In these cases, the increase in $\sigma_{S L}$ and the decrease of $\sigma_{L V}$ correspondingly dominates the $\mathrm{Cu}-5 \mathrm{Sn} / \mathrm{Si}-\mathrm{SiC}$ and $\mathrm{Cu}-7.5 \mathrm{Sn} / \mathrm{Si}-\mathrm{SiC}$ systems, so the $\theta$ of $\mathrm{Cu}-\mathrm{Sn} / \mathrm{Si}-\mathrm{SiC}$ decreases firstly, and then increases, with the Sn concentration rising from $2.5 \%$ to $7.5 \%$. Similarly, two kinds of phases (Figure 5) are also observed in the solidified $\mathrm{Cu}-(5,7.5) \mathrm{Sn}$ alloy drops, and the content of grey phase increases gradually (Figures 3-5). Accordingly, the Sn concentration in the grey phase is also raised.

Figure 6 exhibits the interfacial microstructure of $\mathrm{Cu}-10 \mathrm{Sn} / \mathrm{Si}-\mathrm{SiC}$ systems after $\mathrm{Si}$ ion implantation. Compared with $\mathrm{Cu}-(2.5,5,7.5) \mathrm{Sn} / \mathrm{Si}-\mathrm{SiC}$ systems, the $\mathrm{Cu}-10 \mathrm{Sn} / \mathrm{Si}-\mathrm{SiC}$ presents relatively high contact angles (Figure 2). However, it is puzzling that the molten $\mathrm{Cu}-10 \mathrm{Sn}$ alloy has the lowest surface energy among the four $\mathrm{Cu}-\mathrm{Sn}$ alloys, and thus theoretically the $\mathrm{Cu}-10 \mathrm{Sn} / \mathrm{Si}-\mathrm{SiC}$ systems should present excellent wettability, according to Young's equation. From Figure 6, only a continued graphite layer is closely attached to the $\mathrm{SiC}$ substrate, which is due to the fact that the high $\mathrm{Sn}$ concentration in $\mathrm{Cu}$ alloys can reduce the activity of $\mathrm{Cu}$ element, and thus the chemical reaction is limited at the interface. According to the reactive production control (RPC) model [26,27], wetting in the reactive system is predominated by the final interfacial production at the interface and triple region. Because the molten drop has a poor wettability on the graphite layer, there is relatively poor wettability of $\mathrm{Cu}-10 \mathrm{Sn}$ on $\mathrm{Si}-\mathrm{SiC}$ substrates. Moreover, the interfacial chemical reaction between $\mathrm{Cu}-10 \mathrm{Sn}$ and $\mathrm{Si}-\mathrm{SiC}$ becomes weaker and weaker as the $\mathrm{Si}$ ion dose rises, resulting in a thinner graphite layer and higher contact angle. 

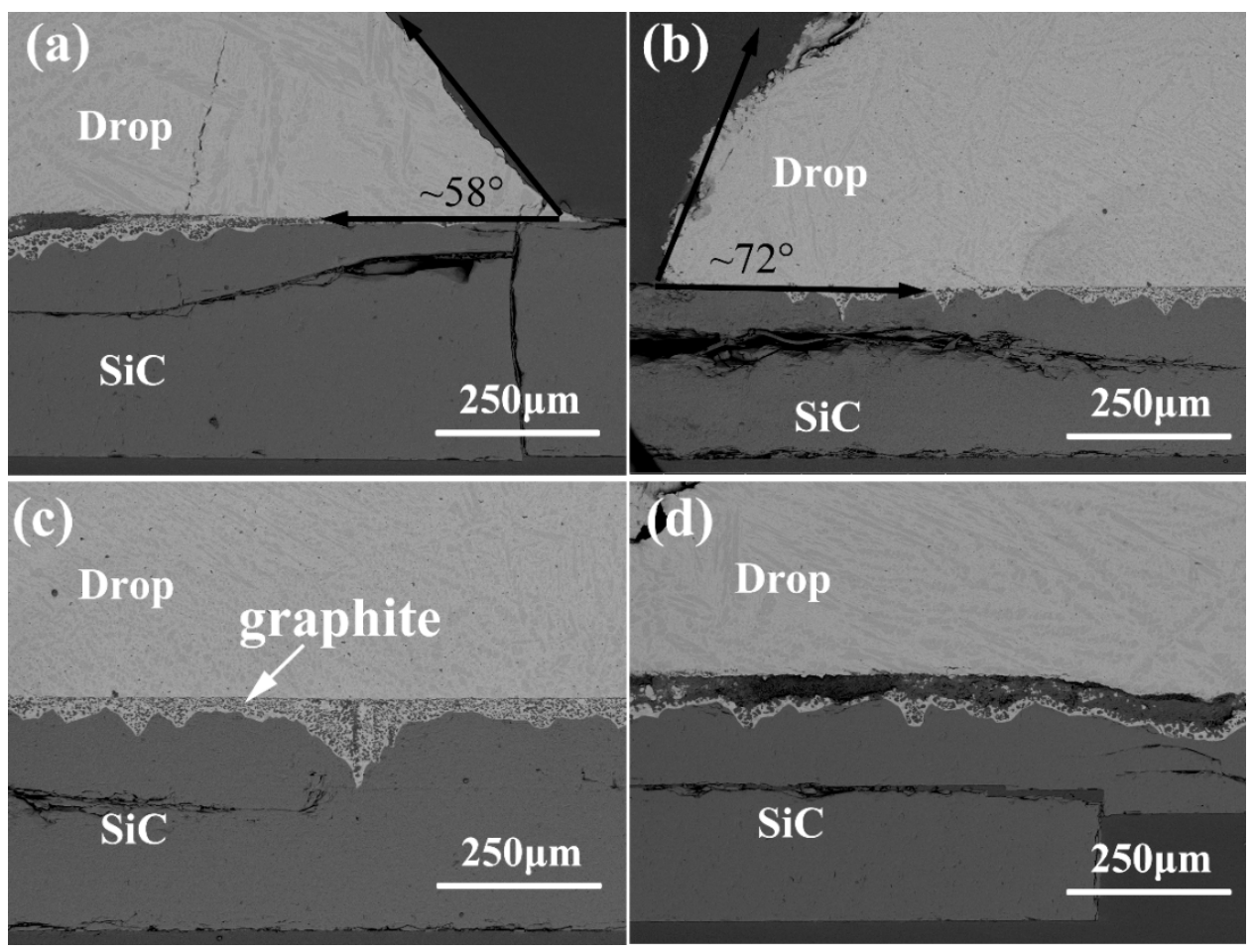

Figure 6. Interfacial BSE images of $\mathrm{Cu}-10 \mathrm{Sn} / \mathrm{SiC}$ systems after the $\mathrm{Si}$ ion implantation of $(\mathbf{a}, \mathbf{c}) 5 \times 10^{15}$ and $(\mathbf{b}, \mathbf{d}) 5 \times 10^{16}$ ions $/ \mathrm{cm}^{2}$.

\section{Conclusions}

The wetting of molten Cu-(2.5, 5, 7.5, 10) Sn on Si-implanted SiC substrates was studied, and the effects of $\mathrm{Si}$ ion doses and $\mathrm{Sn}$ concentration in $\mathrm{Cu}$ alloys on the wettability were analyzed. The $\mathrm{Si}$ ion can markedly enhance the wetting of $\mathrm{Cu}-\mathrm{Sn} / \mathrm{SiC}$ systems; however, the contact angle of $\mathrm{Cu}-\mathrm{Sn}$ on $\mathrm{Si}-\mathrm{SiC}$ substrate partly increases, with the Si implantation dose increasing from $5 \times 10^{15}$ to $5 \times 10^{16}$ ions $/ \mathrm{cm}^{2}$. The wetting of $\mathrm{Cu}-\mathrm{Sn} /(\mathrm{Si}-) \mathrm{SiC}$ systems is closely related to the increasing solid-liquid interfacial energy originated from the decreasing interfacial chemical reaction and the decreasing liquid-vapor surface energy, with the Sn concentration increasing from $2.5 \%, 5 \%$ and $7.5 \%$ to $10 \%$. In particular, a higher Sn concentration of $\geq 7.5 \%$ can obviously reduce the activity of $\mathrm{Cu}$, resulting in a relatively weak interfacial reaction and a higher contact angle $\left(>40^{\circ}\right)$. The above work and conclusions provide a novel way to change the surface properties of ceramic and improve the wettability of the metal/SiC ceramic system, which can further expand the prospective application area of $\mathrm{SiC}$ ceramic. However, changes of the surface state of $\mathrm{SiC}$ after ion implantation in an atomic scale, i.e., the ion site in $\mathrm{SiC}$ lattice and the lattice distortion of $\mathrm{SiC}$, were less straightforward. In the future, the first-principle calculations based on density functional theory (DFT) and Ab-initio molecular dynamics (AIMD) simulation can be performed to study the changes in atomic scale after the ion implantation.

Author Contributions: Conceptualization, X.Z.Z. and A.A. (Awais Ahmad); methodology, A.A. (Asma Alothman), P.H.X., and X.Z.Z.; software, S.H.; validation, A.A. (Awais Ahmad) and S.H.; formal analysis, S.H.; investigation, G.J.Q.; resources, A.A. (Asma Alothman).; data curation, G.W.L.; writing-original draft preparation, A.A. (Awais Ahmad).; writing-review and editing, visualization, X.H.C.; supervision, S.H.; project administration, Y.L.Z.; funding acquisition, X.H.C. All authors have read and agreed to the published version of the manuscript.

Funding: This work was funded by the Researchers Supporting Project Number (RSP-2020/243) King Saud University, Riyadh, Saudi Arabia; National Key R\&D Program of China (2017YFB0310400); the National Natural Science Foundation of China (51572112); the National Natural Science Foundation of Jiangxi (20192BAB206009, 20192BAB206030); the Key Research and Development Plan (BE2019094); the Six Talent Peaks Project (TD-XCL-004); 333 talents project (BRA2017387); and the Qing Lan Project ([2016]15) of Jiangsu Province providing financial support.

Conflicts of Interest: The authors declare no conflict of interest. 


\section{References}

1. Fitriani, P.; Septiadi, A.; Hyuk, J.D.; Yoon, D.H. Joining of SiC monoliths using a thin MAX phase tape and the elimination of joining layer by solid-state diffusion. J. Eur. Ceram. Soc. 2018, 38, 3433-3440. [CrossRef]

2. Liu, J.W.; Zhou, X.B.; Tatarko, P.; Yuan, Q.; Huang, Q. Fabrication, microstructure, and properties of $\mathrm{SiC} / \mathrm{Al}_{4} \mathrm{SiC}_{4}$ multiphase ceramics via an in-situ formed liquid phase sintering. J. Adv. Ceram. 2020, 9, 193-203. [CrossRef]

3. Zhang, W.; Yamashita, S.; Kita, H. Progress in tribological research of SiC ceramics in unlubricated sliding-A review. Mater. Des. 2020, 190, 108528. [CrossRef]

4. Pervaiz, M.; Ahmad, I.; Yousaf, M.; Kirn, S.; Munawar, A.; Saeed, Z.; Rashid, A. Synthesis, spectral and antimicrobial studies of amino acid derivative Schiff base metal ( $\mathrm{Co}, \mathrm{Mn}, \mathrm{Cu}$, and $\mathrm{Cd}$ ) complexes. Spectrochim. Acta Part A Mol. Biomol. Spectrosc. 2019, 206, 642-649.

5. Eustathopoulos, N.; Nicholas, M.G.; Drevet, B. (Eds.) Wettability at High Temperatures; Elsevier Science Ltd.: Kidlington, UK, 1999; Volume 3.

6. Huang, Z.K.; Liu, H.; Liu, G.W.; Wang, T.T.; Zhang, X.Z.; Wu, J.; Wan, Y.G.; Qiao, G.J. Influences of surface polarity and Pd ion implantation on the wettability of Al-12Si(-2Mg)/SiC systems. Mater. Chem. Phys. 2018, 211, 329-334.

7. Song, Y.Y.; Liu, D.; Hu, S.P.; Song, X.G.; Lei, Y.Z.; Cao, J. Brazing of metallized SiC ceramic to GH99 superalloy using graphene nanoplatelets reinforced AgCuTi composite filler. Ceram. Int. 2019, 45, 8962-8970. [CrossRef]

8. Kashif, M.; Ngaini, Z.; Harry, A.V.; Vekariya, R.L.; Ahmad, A.; Zuo, Z.; Alarifi, A. An experimental and DFT study on novel dyes incorporated with natural dyes on titanium dioxide $\left(\mathrm{TiO}_{2}\right)$ towards solar cell application. Appl. Phys. 2020, 126, 1-13. [CrossRef]

9. Barlak, M.; Piekoszewski, J.; Sartowska, B.; Waliś, L.; Starosta, W.; Kierzek, J.; Pochrybniak, C.; Kowalska, E. Wettability of carbon and silicon carbide ceramics induced by their surface alloying with $\mathrm{Zr}$ and $\mathrm{Cu}$ elements using high intensity pulsed plasma beams. Nukleonika 2012, 57, 477-483.

10. McCafferty, E. Effect of Ion Implantation on the Corrosion Behavior of Iron, Stainless Steels, and Aluminum-A Review. Corrosion 2001, 57, 1011-1029. [CrossRef]

11. Zhao, S.T.; Valenza, F.; Liu, G.W.; Muolo, M.L.; Qiao, G.J.; Passerone, A. Surface characterization of Mo-implanted $6 \mathrm{H}-\mathrm{SiC}$ by high temperature non-reactive wetting tests with the Ni-56Si alloy. Ceram. Int. 2014, 40, 7227-7234. [CrossRef]

12. Huang, Z.K.; Xu, W.L.; Liu, G.W.; Wang, T.T.; Zhang, X.Z.; Qiao, G.J. Wetting and interfacial behavior of molten Al-Si alloys on SiC monocrystal substrates: Effects of $\mathrm{Cu}$ or $\mathrm{Zn}$ addition and Pd ion implantation. J. Mater. Sci. Mater. Electron. 2018, 29, 17416-17424. [CrossRef]

13. Zhu, Y.L.; Zhang, M.F.; Zhang, X.Z.; Huang, Z.K.; Liu, G.W.; Qiao, G.J. Wetting and interfacial behavior of $\mathrm{Cu}-\mathrm{Al} / \mathrm{SiC}$ systems: Influences of $\mathrm{Si}$ ion implantation and Al concentration. J. Alloys Compd. 2020, 824, 153972. [CrossRef]

14. Fu, W.; Song, X.G.; Tian, R.C.; Lei, Y.Z.; Long, W.M.; Zhong, S.J.; Feng, J.C. Wettability and joining of SiC by Sn-Ti: Microstructure and mechanical properties. J. Mater. Sci. Technol. 2020, 40, 15-23. [CrossRef]

15. Yang, J.; Huang, J.H.; Ye, Z.; Chen, S.H.; Ji, R.; Zhao, Y. Influence of interfacial reaction on reactive wettability of molten Ag-Cu-X wt.\%Ti filler metal on SiC ceramic substrate and mechanism analysis. Appl. Surf. Sci. 2018, 436, 768-778. [CrossRef]

16. Hussain, S.; Yang, X.; Aslam, M.K.; Shaheen, A.; Javed, M.S.; Aslam, N.; Qiao, G. Robust TiN nanoparticles polysulfide anchor for $\mathrm{Li}-\mathrm{S}$ storage and diffusion pathways using first principle calculations. Chem. Eng. J. 2020, 391, 123595.

17. Wang, T.T.; Yang, Y.; Ren, Y.B.; Zhu, D.Y.; Zhang, T. Reactive wetting of Ni-Si alloys on graphite substrates: Effects of Si and Ni. RSC Adv. 2015, 5, 90866-90870. [CrossRef]

18. Rado, C.; Drevet, B.; Eustathopoulos, N. The role of compound formation in reactive wetting: The $\mathrm{Cu} / \mathrm{SiC}$ system. Acta Mater. 2000, 48, 4483-4491. [CrossRef]

19. Zhou, B.F.; Wang, J.F.; Feng, K.Q. Study on the wetting interface of Zr-Cu alloys on the SiC ceramic surface. RSC Adv. 2020, 10, 3487-3492. [CrossRef]

20. Sarafraz, M.M.; Safaei, M.R.; Goodarzi, M.; Yang, B.; Arjomandi, M. Heat transfer analysis of Ga-In-Sn in a compact heat exchanger equipped with straight micro-passages. Int. J. Heat Mass Transf. 2019, 139, 675-684. [CrossRef] 
21. Sarafraz, M.M.; Jafarian, M.; Arjomandi, M.; Nathan, G.J. Potential use of liquid metal oxides for chemical looping gasification: A thermodynamic assessment. Appl. Energy 2017, 195, 702-712. [CrossRef]

22. Sarafraz, M.M.; Tran, N.N.; Pourali, N.; Rebrov, E.V.; Hessel, V. Thermodynamic potential of a novel plasma-assisted sustainable process for co-production of ammonia and hydrogen with liquid metals. Energy Convers. Manag. 2020, 210, 112709. [CrossRef]

23. Okamoto, H. Supplemental Literature Review of Binary Phase Diagrams: Ag-Ho, Ag-Tb, Ag-Y, Cd-Na, Ce-Sn, Co-Dy, Cu-Dy, Cu-Sn, Ir-Pt, Mg-Pb, Mo-Ni, and Sc-Y. J. Phase Equilibria Diffus. 2014, 35, $208-219$. [CrossRef]

24. Amore, S.; Ricci, E.; Lanata, T.; Novakovic, R. Surface tension and wetting behaviour of molten Cu-Sn alloys. J. Alloys Compd. 2008, 452, 161-166. [CrossRef]

25. Okamoto, H. Supplemental literature review of binary phase diagrams: Ag-Ni, Ag-Zr, Au-Bi, B-Ni, Co-Sb, $\mathrm{Cu}-\mathrm{Mn}, \mathrm{Cu}-\mathrm{Si}, \mathrm{Cu}-\mathrm{Zn}, \mathrm{Fe}-\mathrm{Zr}$, Li-Sb, Mg-Pu, and Si-Zr. J. Phase Equilibria Diffus. 2018, 39, 87-100. [CrossRef]

26. Eustathopoulos, N. Progress in understanding and modeling reactive wetting of metals on ceramics. Curr. Opin. Solid State Mater. Sci. 2005, 9, 152-160. [CrossRef]

27. Eustathopoulos, N. Wetting by liquid metals-Application in materials processing: The contribution of the grenoble group. Metals 2015, 5, 350-370. [CrossRef]

(C) 2020 by the authors. Licensee MDPI, Basel, Switzerland. This article is an open access article distributed under the terms and conditions of the Creative Commons Attribution (CC BY) license (http://creativecommons.org/licenses/by/4.0/). 